\title{
ВЛИЯНИЕ ЧРЕЗВЫЧАЙНЫХ СИТУАЦИЙ НА РАЗВИТИЕ СИСТЕМЫ ОБРАЗОВАНИЯ
}

\author{
Бобкова И.А.
}

В работе рассмотрены основные проблемы среднего и высшего образования с точки зрения перехода обучающегося на более высокую ступень образования, а также влияние эпидемиологической обстановки 2020 года на приемную компанию в университеть и колледжи РФ.

DOI: $10.20537 /$ mce2021econ07

Введение. Двадцать первый век предъявляет новые требования к системе образования и в России, и в зарубежных странах. Это связано и с процессами глобализации, и с информатизацией общественной жизни, и с цифровизацией во всех сферах экономики, а также рядом других причин.

Российская система среднего и высшего образования, находящаяся в процессе непрекращающегося реформирования в течение последних тридцати лет, испытывает огромную нагрузку на все свои звенья - от начальной школы до магистратуры и аспирантуры. Причем, если не закрывать глаза на подтасовывание данных о качестве подготовки учащихся, то следует признать, что реформирование образования негативно сказывается на учебном процессе. Пандемия COVID-19 высветила все существующие проблемы российского образования. Особенно ярко это проявилось во время приемной компании в вузы и колледжи летом 2020 г. Итоги этой компании сейчас активно обсуждаются на всех уровнях, от ректоров до министра и научного сообщества, принимаются решения, призванные исправить обнаруженные недостатки. Решения, подчас способные спровоцировать еще большие проблемы. Анализ влияния таких чрезвычайных ситуаций, как пандемия, экологическая или техногенная катастрофа, политический кризис, на систему образования и способности системы противостоять кризисным явлениям - крайне актуальная задача 2020х годов.

Школьное, среднее профессиональное, вузовское образование это те вопросы, которые касаются каждой семьи. Вот почему реакция 
общества на любые изменения, происходящие в сфере образования, обычно бывает бурной и мгновенной. Учебные годы 2019-2020 и 2020-2021 стали нешуточным испытанием для всей российской образовательной системы. Автор и ее семья переживали события, связанные с пандемией вместе со всей страной. Потому что автор: (1) преподаватель университета в г. Москве; (2) преподаватель курсов по подготовке абитуриентов - выпускников 11 класса, - к сдаче ЕГЭ и выпускников колледжей к вступительным испытаниям в вузе; (3) мама выпускника 2020 г., досконально знакомая с реалиями школьного образования, ЕГЭ2020, вступительной компании - 2020.

Новые вызовы XXI века. Мир в 21 веке меняется очень быстро. И различным системам, и институтам приходится также быстро подстраиваться к изменяющемуся внешнему миру. Какие же новые глобальные проблемы стоят перед системой образования? Прежде всего глобализация, информатизация общественной жизни, цифровизация во всех сферах экономики, в т.ч.в экономике знаний [1].

Реформирование системы образования в России - это длительный и хронический процесс. Так повелось еще со времен Петра Великого. Особенно активно система реформировалась в 20-м веке и начале 21-го. Практически каждое десятилетие - какие-то нововведения. Наиболее существенные изменения произведены в 1920-30-х гг., 1960-70-х, 19902010-х. После распада советской системы в 1990-х гг. преподавателям и директорам школ, и ректорам университетов была предоставлена большая свобода при формировании читаемых курсов, выборе учебников, учебных программ, большое значение придавалось гуманитарной составляющей образования. В 2000-е - полный переход на 11-летнее образование с 4-летним начальным, введение ЕГЭ, переход на Болонскую систему высшего образования. В 2010-е проведена масштабная трансформация российской системы образования: школа полностью перешла на систему ОГЭ и ЕГЭ, вузы на бакалавриат, специалитет и магистратуру (двухуровневая система высшего образования), СПО - на систему «колледж», которая в России стала неким агрегатом ПТУ и техникумов, были официально закреплены различные формы обучения (очная, очнозаочная (бывшее вечернее образование), заочная, экстернат, семейное образование, сетевое обучение, электронное и дистанционное обучение). Укрупнение (объединение) школ и вузов, слияние школ с детскими садами, массовое закрытие сельских школ, школ для особых детей, вечерних школ, сокращения учителей, школьных психологов, информа- 
тизация системы образования, ввод новой системы оплаты труда педагогов, подушевое финансирование, переход на приоритет платных услуг, в т.ч. в школах, введение ФГОСов. Масштаб затронутых ступеней образования огромный: старшие группы детского сада - начальная школа - средняя школа - старшая школа - колледж (СПО) - бакалавриат, специалитет, магистратура - аспирантура.

Экономика поступления - 2020. Ст. 43 Конституции РФ гарантирует всем гражданам России получение бесплатного дошкольного, основного общего и среднего профессионального образования и бесплатного высшего образования по конкурсу. Ст.19 Конституции РФ гарантирует гражданам равные права и возможности независимо от их пола, расы, национальности, места жительства, отношения к религии, убеждений, и других обстоятельств.

Государство гарантирует всем молодым людям равные права при получении образования. Гарантирует де-юро. А действуют ли эти гарантии де-факто? Гарантировано ли абсолютно любому юному гражданину РФ равенство при поступлении в университет в результате равенства и бесплатности образования в старших классах общеобразовательной школы?

Первое, что приходит в голову, когда мы говорим о неравенстве в образовании - финансовое положение семьи. Рассмотрим обычные средние расходы средней семьи выпускника общеобразовательной школы.

1) Репетиторы: от 1200 до 4000 руб. за занятие (но есть варианты и по 10-15 тысяч), минимум - 1 предмет, максимум - 5 .

2) Выездные школы, сборы, лагеря: в среднем 15-20 тыс. руб. за неделю пребывания.

3) Выезды на олимпиады: от полностью оплаченных школой поездок, оплаты школой билетов туда-обратно до полной оплаты родителями примерно 10-14 дней пребывания (цена - в зависимости от дальности поездки и уровня пансионата пребывания).

4) «Бесплатные» заочные школы: оплата той или иной услуги в зависимости от аппетитов школы («нормально» - 3000-5000 руб.).

5) Онлайн курсы и курсы по подготовке к ЕГЭ, ДВИ: группы - в среднем 500 руб. за 1.5 часа.

6) Учебники и учебные пособия: в зависимости от вуза и набора сдаваемых предметов, стандартно 5-15 тыс. в год. 
Теперь рассмотрим расходы второго полугодия семьи конкретного выпускника в конкретной специализированной школе г. Москвы, выбравшего для себя один из топовых московских технических университетов.

1) Репетиторы в неделю в период январь-июнь 2020 г.:

- Математика (подготовка к ДВИ в МГУ, частично подготовка к олимпиадам) - 4000 руб., с сентября 11 класса.

- Информатика -2000 руб., с октября 11 класса.

- Русский язык/литература - 1700 руб., с ноября 11 класса.

- Физика (разовые консультации) - всего 20 тыс. руб., если разделить на 5 месяцев, т.е. примерно 4000 руб. в месяц или 1000 руб. в неделю, с апреля разовыми платежами.

Итого: 8700 руб.в неделю.

С учетом дополнительных консультаций перед ЕГЭ, олимпиадами, сочинением и т.п. с 01.09.19 по 01.07.20 потрачено около 300 тыс. руб.

2) ЗФМШ - «добровольное пожертвование» 5000 руб. за год (разовая выплата).

3) Литература - 2 заказа: $5700+7500=13300$ руб. за март-май. Была еще куплена учебная литература в октябре, но точная цена не сохранена, порядка 7000 руб.

4) Международная олимпиада по физике IEFA2019 - пребывание бесплатно как члена команды лицея (оплачено школой), железнодорожные билеты примерно 5000 руб.

5) Физмат сборы с выездом в лагере в октябре 2019 г. - 36 тыс. руб. (обычно 2-3 выездных школы или сборов в течение учебного года).

Итак, за год потрачено примерно 366 тыс. руб. Причем, это минимум, какие-то более мелкие расходы сюда не вошли.

Одними финансами поступление выпускника не определяется. За спиной выпускника стоят не только родители с их финансами, но и хорошая школа. За спиной данного конкретного выпускника стояла лингвистичекая школа с 1 по 7 класс и физико-математическая школа с 8 по 11 класс с прекрасным математиком, физиком, химиком и преподавателем русского языка и литературы, с факультативом по подготовке к физическим и математическим олимпиадам РСОШ, которые и обеспечили прекрасную базовую подготовку к ЕГЭ. На выходе школа получила нескольких 299-балльников, несколько 100-балльников и остальной класс с суммарными баллами ЕГЭ более 280 баллов (за исключением 2 или 3 человек, 
«проколовшихся» на 270-275 баллов), призера ВсОШ, нескольких победителей олимпиад РСОШ 1-го уровня и остальной класс - призеры и победители РСОШ 2-го уровня. Результат: поступление данного выпускника в выбранный вуз на «специальность мечты» на бюджетной основе.

Таким образом, поступлению конкретного выпускника в вуз мечты способствовала хорошая школа, финансовые затраты, доступ к литературе, сборам, летним школам, мероприятиям столичных вузов, финальным очным турам олимпиад РСОШ и ВсОШ, помощь и поддержка дома со стороны родных, имеющих физико-математическое и техническое образование. А это означает, что при гарантированном государством равенстве при поступлении в вуз те выпускники, которым повезло с местом рождения, семьей, уровнем школы и профильных учителей, оказываются «равнее». Что, однако, совершенно не означает, что они менее достойны, чем те, кто такими возможностями не обладает. Это умные, ответственные, трудолюбивые ребята, потратившие массу усилий для поступления на бюджет в избранный университет.

Означает ли это, что у умных, трудолюбивых ребят, которым не повезло с исходными вводными параметрами, совсем нет шансов? Нет, не означает. Для достижения аналогичного результата им потребуется приложить больше (намного больше) усилий. И для этого им нужен дешевый и доступный Интернет с бесплатными закаченными учебниками, онлайн курсами, дешевыми репетиторами, пособиями по подготовке к ЕГЭ. Потому что, если у выпускника отпадают олимпиады, выездные школы, сборы и т.п., поездки, которые требуют денег, то выпускник может набрать максимальный балл только на ЕГЭ. И поступить в «вуз мечты», если этот балл окажется достаточно высоким.

Чрезвычайные ситуации. В планы поступления абитуриентов свои коррективы внесла и чрезвычайная ситуация - пандемия COVID-19. И поставила перед системой образования новые задачи. Но пандемия - это лишь частный случай. Возможны самые разные катастрофы: экологические, техногенные (в т.ч. применение химического оружия), эпидемии (в т.ч. применение бактериологического оружия), терроризм, вооруженные конфликты, политические кризисы (в т.ч. революции), субъективные причины (в т.ч. ошибочные указы, законы, распоряжения на федеральном уровне).

Как любая чрезвычайная ситуация, пандемия обострила проблемы цифровизации и информатизации образовательного процесса, и ранее существовавшие в нашей системе образования. Общий вывод, 
который можно сделать по итогам весны, осени и летней приемной компании 2020 г. - система российского образования продемонстрировала неготовность к работе в условиях эпидемий, а в более обобщенном виде - к работе в условиях ЧС.

Хронологически действия министерств выглядели так: $23.03-$ уход на дистанционное обучение; 27.03. — перенос ЕГЭ с 25.05 на 08.06 (ОГЭ на 09.06, 1-й день); 18.05. - отмена ЕГЭ, ОГЭ до выяснения эпидемиологической ситуации; 11.06. — отмена ОГЭ; 15.06. — перенос ЕГЭ на 03.07; введение «пробных экзаменов» 29-30.06. Все это производило впечатление хаоса и полного непонимания руководящих органов, что же им следует делать с выпускниками. Дезориентировало выпускников, учителей, ректоров вузов. Если все прошло спокойно и в рабочей обстановке - это исключительно заслуга конкретного директора и конкретных школ и вузов. Рассмотрим различные заинтересованные группы.

Дети. MAXIMUM Education провела опрос среди 1100 выпускников из различных регионов страны о влиянии дистанта и пандемии на результаты ЕГЭ: 43\% ребят считают, что дистант никак не повлияет на результаты ЕГЭ, 39\% уверены, такой формат скажется негативно, 18\% заявили о позитивном влиянии дистанта.

Автор провела несколько собственных опросов.

Особое мнение. Москва. Физмат лицеи и классы (из топ-50), 37 респондентов: $49 \%$ - позитивное влияние, $32 \%$ - негативное влияние, 19\% не определились. Россия (не Москва): физмат лицеи крупных городов, 12 опрошенных, победители олимпиад РСОШ и финала ВсОШ: 1 человек - негативное влияние, 11 человек - никак не повлиял.

Причины. Москва: а) 2 месяца преподаватели непрофильных предметов спрашивали «спустя рукава»; б) можно было отключить камеру и звук и заниматься своими предметами; в) можно было не тратить время на школу и заниматься с репетиторами; г) не тратилось время на дорогу; д) страдали объяснения предметов ЕНЦ. Россия (не Москва, поступившие по БВИ): а) заработав БВИ в марте, ребята не собирались «убиваться» на ЕГЭ; б) кому надо было подтверждать олимпиаду 75 баллами ЕГЭ, решали варианты без напряжения и волнений; в) на ребят, сдававших ЕГЭ «по-настоящему», остальные смотрят как на героев.

Родители. Основная ответственность за обучение школьников была переложена на родителей, у которых часто не было ни навыков, ни времени, ни техники, чтобы помочь детям. С чем были связаны основные жалобы родителей: (1) родители вынуждены помогать детям, (2) ро- 
дители жалуются на огромный объем домашних заданий, (3) родители считают, что дистант превратился де-факто в самостоятельное обучение, (4) отсутствие у родителей навыков, времени, (5) проблемы с техникой либо вся семья, несколько детей претендуют на один компьютер, либо необходимы затраты на технику, (6) невозможность поделить одну комнату между детьми и родителями на удаленке, (7) для родителя - учителя дистант стал катастрофой, (8) родители учеников 9, 11 классов наняли дополнительных репетиторов по всем предметам ОГЭ, ЕГЭ, хотя изначально не планировали.

Учителя. Эмоциональное напряжение, информационная перегрузка, жалобы на здоровье при совершении полного перехода на дистанционную работу - основные проблемы, отмеченные практически всеми учителями. В зоне риска оказались школы, находящиеся в сельских районах, а также в малых и средних городах: $52 \%$ учителей отмечают проблемы с техникой и интернетом у детей, $21 \%$ - сложности у самого учителя, 95\% учителей отметили рост нагрузки на учителя и $70 \%$ - на ученика. Например, в Республике Башкортостан: до марта 2020 г. 64\% учителей имели отдельные уроки или курсы в цифровом формате, после - 93\% учителей. Способ достижения прироста - работа 24/7 и большие материальные затраты [3].

Основные проблемы, которые называют педагоги: (1) низкая скорость интернета, качество связи, (2) написание отчетов, (3) технические средства, (4) психологические проблемы и здоровье, (5) некачественное обучение детей с ОВ3 (т.е. полностью проваленная четвертая четверть), (6) катастрофическая ситуация при преподавании творческих предметов, (7) вмешательство родителей в учебный процесс (подсказки, агрессия, присутствие на уроках), (8) финансы.

Дети, родители и учителя отмечали следующие плюсы и минусы образования в дистанционном формате. Плюсы: независимость от места и времени, гибкость; охват аудитории; доступность учебных материалов; зрелищность; мотивированность; использование современных ИКТ; социальный лифт; возможность обучения в нескольких вузах (студенты); индивидуальная траектория; увеличивается степень самостоятельности обучения. Минусы: зависимость от технических средств; сильная зависимость от качества используемых учебных материалов, от мастерства педагогов; высокая трудоемкость создания интерактивного контента; навык работы с информацией должен быть хорошо развит; снижение мотивации к учебе без жесткого визуального контроля препо- 
давателя; особые формы контроля, трудности в его качественном проведении; нагрузка на зрение, позвоночник, нервную систему и учителя, и учащегося; значительные финансовые затраты; трудности реализации рабочих программ по спорту, творческим дисциплинам, работе с детьми с ВО3, практикумов; отсутствие живого общения, чувства локтя у учеников, командного духа, энергии учителя; увеличивается степень самостоятельности обучения, что сильно зависит от уровня подготовленности или неподготовленности учащихся.

В статье [4] очень точно подмечено: «Постепенно, варясь в своем соку, наступая на грабли своих коллег из других школ, будем осваивать новые технологии, и, в конечном итоге, спустя поколения испорченных детских умов, придем к пониманию этой технологии, и кому-то реально повезет. Но не нынешним детям, что заканчивают в этом году 11-е классыl».

При подготовке непосредственно к выпускным экзамена были выявлены следующие тенденции: а) для 11-классников - сведение контроля к сугубо формальным показателям, результаты ЕГЭ, не вполне соответствующие подготовке и возможностям учеников (от негласного разрешения списывать в одних школах до мер на уровне геноцида в других); б) для выпускников колледжей - фактическое прекращение практических занятий, фиктивный прием выпускных работ, экзамены по профмастерству в онлайн, невозможность качественной индивидуальной подготовки; в) университеты - недостатки информационноцифрового обеспечения вузов.

После ЕГЭ настала очередь вузов. Приемная компания - 2020 выявила следующие серьезные проблемы вузов по всей стране: (1) олимпиады, финалы которых закончились к концу марта, а результаты были получены в апреле, «спасли» многих выпускников 2020 г. от стрессов, связанных с переносами ЕГЭ и процедурами проведения самого экзамена; (2) дистанционный прием документов расширил «клиентскую» базу некоторых вузов и колледжей, увеличил обмен абитуриентами между Москвой и СПб, близкими волжскими и уральскими городами (Казань - Н.Новгород, Самара-Саратов, ЕкатеринбургЧелябинск и т.п.), но в некоторых вузах увеличил стрессы, связанные с приемом документов; (3) сжатие сроков собственно приема (конец августа), наложение платного приема на бесплатный, невнятность сроков прохождения приема на ЗФО превратила обычный кошмар приемной 
компании в настоящий ужас для нервной системы абитуриентов и их родителей и для членов приемных комиссий.

Заключение. Перед всеми субъектами образовательного процесса - учениками, педагогами, администрациями от завучей в школе до министров образования, - стоят новые вызовы, поставленные самой современной жизнью. И модернизация образовательных учреждений должна происходить таким образом, чтобы этим вызовам соответствовать. В противном случае исправление ошибок станет уже не проблемой системы образования, а проблемой системы национальной безопасности.

\title{
СПИСОК ЛИТЕРАТУРЫ
}

1. Бобкова И.А. Цифровизация образования: начальный этап // // Научнопрактический журнал "Концепиии". 2018. №1(37). С.72-78.

2. Муромиев М.Г. Как реформировали наше образование. Краткая хронология. URL:

https://multiurok.ru/blog/kakrieformirovalinashieobrazovaniiekratkaiakhro nologhiia.html

3. Проблемы перехода на дистанционное обучение в Российской Федерации глазами учителей. Республика Башкортостан // Лаборатория медиакоммуникаций в образовании НИУ ВШЭ. URL: https://cmd.hse.ru/mirror/pubs/share/363055291.pdf

4. Смешно и грустно: про дистанционное образование в школах РФ // Mr. Учитель (Карпов vs Каспаров), статья от 26.03.20. URL:

https://zen.yandex.com/media/buchitel/smeshnoigrustnoprodistancionnoeobrazo vanievshkolahrf5e7cea1469f0af4fe1926b83

\section{IMPACT OF EMERGENCIES ON THE DEVELOPMENT OF THE EDUCATION SYSTEM}

\author{
Bobkova I.A.
}

The paper reviews the main problems of secondary and higher education from the point of view of the student's transition to a higher level of education, as well as the impact of the epidemiological situation in 2020 on the admission company to universities and colleges of the Russian Federation. 